\title{
The Influence of School Leadership Style and School Environment on the Performance of Primary School Teachers in Kisam Tinggi District
}

\author{
Wiwin Hariansyah ${ }^{1 *}$, Happy Fitria ${ }^{2}$, Yenny Puspita ${ }^{2}$ \\ ${ }^{1}$ SD Negeri 02 Kisam Tinggi \\ ${ }^{2}$ University of PGRI Palembang \\ * Corresponding author.Email: winhariansyah028@gmail.com
}

\begin{abstract}
This research aims to determine and analyze the principal's effect and the school environment's leadership style on elementary school teachers' performance in Kisam Tinggi District. The method used in this research is quantitative methods. The data collection tools used were documentation and questionnaires. The conclusion drawn from the research and discussion results that there is a positive and significant influence between the principal's leadership style related to primary school teachers' performance in Kisam Tinggi District with a rX1Y value of $0.725>$ r-table 0.178 There is also a positive influence on the principal's leadership style. The school environment positively and significantly affects primary school teachers' performance in Kisam Tinggi District. It has a significant effect on the principal and the school environment's leadership style on primary school teachers' performance in Kisam Tinggi District.
\end{abstract}

Keywords: Leadership, School Environment, Teacher Performance.

\section{INTRODUCTION}

Education is defined as an absolute need that must be developed because education is the basis for advancing the nation. According to the objectives of national, good education must be managed in an orderly, orderly, and efficient manner to produce something capable of accelerating the nation's civilization based primarily on the creation of general welfare and the intellectual life of our national education itself.

Sunarya stated in [1] that national education is a system that stands on the basis and is inspired by life's philosophy. The purpose is to assist the national interests and ideals. Also, to develop students' potential to be good human beings who believe and fear God Almighty. Then, have a noble character, healthy, well-informed, proficient, creative, independent, and become citizens who democratic and responsible.

Education is the essential thing in human resource development. Teachers as educators certainly have a huge responsibility in carrying out this task. As educators, teachers are a determining factor in enhancing the education quality in schools. Therefore, teachers must improve their performance in carrying out their duties because education in the future requires quality educational professional skills. Teachers' professional performance could be a breath of fresh air for success in the future world.

Good performance has carried out fundamental elements that consist of high loyalty and commitment, related to teaching tasks, understanding and developing learning materials, and discipline in teaching. Also, teachers must have creativity in teaching and collaborate with all school members. Their leadership would become role models for the students. Teachers also must have a good personality, honesty, and objective in guiding students and responsible for doing their duties. Discussing the problem related to the quality of teacher performance could not be separated from the achievement of learning outcomes. This is because teacher performance greatly determines the success of an effective and efficient learning process. Educational goals could be achieved and materialized from good student learning outcomes, which could produce quality graduates. 
Teacher performance is the key that must be worked on. Performance is the appearance of work activities characterized by motion flexibility, rhythm, and work order according to procedures to achieve results that meet the quality, rapidity, and requirements quantity. In line with that, Smith said that performance is "output derive processes, human or otherwise." So performance is the result or output of a process.

[2] Further said that performance is "a continuous communication process, which is carried out by a partnership between a teacher and a student." A good communication process between teachers and students and the school principals and teachers in the learning process could accelerate students' understanding of the teacher's material. This is a performance system that adds value to schools to enhance the quality of students in learning.

Meanwhile, [3] said that performance is "the result obtained based on a certain task/function in a certain period." Thus, performance could be interpreted as a result of a teacher's efforts achieved by abilities and actions in certain situations. This is the hope of all parties, but the reality in the field shows that there are still some teachers whose performance is not optimal.

Many teachers have not worked optimally. From the author's initial observations through interviews with school principals and elementary school supervisors in Kisam Tinggi District, it was found that there were still teachers who taught without making lesson plans, had not utilized existing teaching facilities optimally, and so on.

According to [4], teacher performance is not optimal, disciplinary, and other negative symptoms. This condition is certainly not conducive to school progress, even though teacher performance is an essential target in human resource management. This is directly or indirectly affects work productivity. Teacher performance is indeed something complex and involves various factors.

Correspondingly, [5] their relationship with the organization. Various efforts have been made to improve teacher performance, among others, by increasing teacher professionalism through the principal's leadership style, seminars, courses or high formal education, and coaching and development to support effective learning. In practice, we demand teacher competency developers' expertise and pay attention to various factors that affect a teacher's performance.
Leadership is one factor that affects teacher performance because an organization could succeed or not, partly determined by leadership quality. According to Sutisna in [6], explaining leadership is the process of influencing a person or group's activities to achieve goals in certain situations. So it could be interpreted that leadership is an action taken by individuals to influence and provide direction to other individuals or groups in a particular organization to achieve predetermined goals. Leadership is one of the main factors in organizational life which plays a key role.

According to Thoha in [6], explaining leadership style is a norm of behavior that a person uses to influence others' behavior as he sees it. So it could be interpreted that the leadership style is a method used by a leader in influencing his subordinates.

In this case, the principal will be able to distinguish between an organization and another. The leadership style of the principal in leading will affect the performance of the teacher. Effective and ineffective leadership is the most important thing that a principal must understand in leading an organization or group. Understanding the leadership style will increase a principal's understanding of himself and determine his potential weaknesses and strengths. It could increase understanding of how to treat his subordinates.

Based on preliminary observations through the author's interview with the elementary school teacher board in Kisam Tinggi District, it was found that the leadership style of the principal was different in each school. Also, information was found if there are still principals who do not involve teachers in policymaking, ignore the conditions of teachers who teach, etc. This will certainly affect the performance of teachers in schools.

In addition to the principal's leadership style, one thing that could affect teacher performance is the school environment itself. Nitisemito argued, "The work atmosphere is the whole thing that is around the workers. This could influence them in executing their assigned duties." Another opinion says, "The work environment is outside human factors in an organization, both physical and non-physical.

These physical factors comprise work equipment, the workplace's temperature, density or crowdedness, or noise, workspace area. While non-physical include work relationships that are made. In institutions between superiors and assistants and among staffs". From the 
above factors, it could be said that the work environment could affect the work done.

The condition of the elementary school environment in Kisam Tinggi District is not the same in every school. The authors know this condition based on preliminary observations results through interviews and direct observations at school. The real differences that the authors encounter during observation, for example, differences in buildings and learning support facilities. This condition is thought to affect teacher performance in schools.

This research was conducted to know the effect of the work environment and work motivation on high school teachers' performance in Muara Padang District. The method used in this research is the quantitative descriptive method. There was a positive and significant influence of the work environment and work motivation on high school teachers' performance in Muara Padang District. Therefore, the alternative hypothesis in testing hypotheses 1, 2, and 3 was accepted; This research conducted has similarities in the variables of the school environment's influence on teacher performance. The difference is that this study only examines the effect of the school environment on teacher performance, while the research conducted explores the leadership style of school principals.

[7] Research on Leadership Management in Islamic Education Institutions concludes that Islamic educational institutions' leadership is expected to be creative, innovative, and productive for these educational institutions' sustainability.

\section{METHODS}

This research is an ex-post-facto study, which is a study conducted to examine events that had occurred before the analysis was carried out. Researchers only take data from existing fields. The subjects in this study were elementary school teachers who were in Kisam Tinggi District. Based on preliminary observations, the total number is 172 teachers. All of them are spread over 19 elementary schools in Kisam Tinggi sub-district.

The method used in this research is quantitative methods. The prerequisite test to be carried out is the linearity test used to test whether the dependent and independent variables have a significant linear relationship. Suppose the relationship between two variables is linear. In that case, the score increase for variable $\mathrm{X}$ is followed by an increase in the score for the variable Y. This relationship was tested using SPSS. According to [8] the formula is used to test linearity.

Furthermore, the $\mathrm{F}$ count is consulted with the $\mathrm{F}$ table price with a significance level of $5 \%$. If the Fcount value <from Ftable, then the two variables have a linear effect. Conversely, if Fcount> from the Ftable price, it means that the two variables have a non-linear effect. The multicollinearity test was directed as a condition for using multiple regression analysis in this study. The multicollinearity test was conducted by investigating the magnitude of the independent variables intercorrelation. To test multicollinearity using the Tolerance value and the VIF value. Tolerance processes the selected independent variables that are not clarified by other independent variables.

The conclusion is to compare $\mathrm{t}$ count with $\mathrm{t}$ table. This test is used to accept or reject the hypothesis. If $t$ count is smaller than the table with an error level of $5 \%$, this variable's effect is not significant, or the hypothesis is rejected. Conversely, if the t-count is greater than or equal to the t-table at a significant level of $5 \%$, this variable's influence is significant, or the hypothesis is accepted. The researcher analyzed the data using multiple regressions to determine the truth of hypothesis 3, namely: the effect of academic qualifications and work motivation of educators and education staff on the quality of madrasah academic services. According to Sugiyono (2019), multiple regression analysis is used by researchers if they intend to predict how the dependent variable will be when two independent variables are manipulated in value.

\section{RESULTS AND DISCUSSION}

The data of the results of multiple linear regression analysis of the principal of leadership style variable (X1) and the school environment (X2) on the teacher performance variable $(\mathrm{Y})$ could be seen in the following table: 
Table.1. The results of the linear regression test $\mathrm{X} 1, \mathrm{X} 2$ against Y

\begin{tabular}{|c|c|c|c|c|c|c|}
\hline \multicolumn{7}{|c|}{ Coefficients } \\
\hline & \multirow{2}{*}{ Model } & \multicolumn{2}{|c|}{$\begin{array}{l}\text { Unstandardized } \\
\text { Coefficients }\end{array}$} & $\begin{array}{l}\text { Standardized } \\
\text { Coefficients }\end{array}$ & \multirow{2}{*}{$\mathrm{t}$} & \multirow{2}{*}{ Sig. } \\
\hline & & B & $\begin{array}{l}\text { Std. } \\
\text { Error }\end{array}$ & Beta & & \\
\hline \multirow{3}{*}{1} & (Constant) & $\begin{array}{c}22.3 \\
50\end{array}$ & 7.183 & & 3.111 & $\begin{array}{l}.00 \\
2\end{array}$ \\
\hline & $\begin{array}{l}\text { Leadership } \\
\text { Style }\end{array}$ & $\begin{array}{c}0.55 \\
3\end{array}$ & 0.075 & 0.571 & 7.426 & $\begin{array}{l}.00 \\
0\end{array}$ \\
\hline & $\begin{array}{c}\text { Environmental } \\
\text { _School }\end{array}$ & .246 & 0.076 & 0.250 & 3.250 & $\begin{array}{l}.00 \\
2\end{array}$ \\
\hline \multicolumn{7}{|c|}{ a. Dependent Variable: Performance Teacher } \\
\hline
\end{tabular}

The calculation of multiple linear regression analysis shows that the regression line equation is: $\mathrm{Y}^{\prime}=$ $22,350+0,553(\mathrm{X} 1)+0,246(\mathrm{X} 2)$. which means that the constant value of teacher performance is 22.350 if there are no changes in the two variables $\mathrm{X} 1$ and $\mathrm{X} 2$. The teacher performance value will increase by 0.553 every time. There is an additional value of 1 in the leadership style variable with the assumption for the fixed school environment variable's value. The teacher performance value will also increase by 0.346 if there is an additional value of 1 in the school environment variable, assuming the principal's leadership style's value is fixed. While the data from the results of regression analysis ( $\mathrm{F}$ test) variable principal leadership style (X1) and school environment (X2) together on teacher performance variables (Y).
Table. 2 The results of the F X1 test against $\mathrm{Y}$

\begin{tabular}{|c|c|c|c|c|c|c|}
\hline \multicolumn{7}{|c|}{ ANOVA } \\
\hline & Model & $\begin{array}{l}\text { Sum of } \\
\text { Squares }\end{array}$ & Df & $\begin{array}{l}\text { Mean } \\
\text { Sauare }\end{array}$ & $\mathbf{F}$ & Sig. \\
\hline \multirow{3}{*}{1} & $\begin{array}{l}\text { Regressio } \\
\mathrm{n}\end{array}$ & 5674.167 & 2 & 2837.084 & 76.359 & $.000^{\mathrm{b}}$ \\
\hline & Residual & 4384.262 & 118 & 37.155 & & \\
\hline & Total & 10058.430 & 120 & & & \\
\hline \multicolumn{7}{|c|}{ a. Dependent Variable: Performance Teacher } \\
\hline & dictors: (C & $\operatorname{tant)}$ & & & & \\
\hline
\end{tabular}

Based on the value of Fcount $=76.359$ with a significant amount of $0.000 .<0.05$, the value of Ftable and df obtained Ftable of 3.19. Then obtained Fcount $>$ Ftable. Therefore, the null hypothesis, which reads HO: there is no significant effect between the principal's leadership style and the school environment on teacher performance, is rejected. And the hypothesis that says Ha: There is a positive and significant effect between the principal's leadership style and the school environment together on teacher performance, accepted. This proves a significant effect between the principal's leadership style and the school environment on teacher performance.

This research is a descriptive quantitative study that purposes to determine whether there is an influence between the principal's leadership style and the school environment on elementary school teachers' performance in Kisam Tinggi district.

The calculation of the principal's leadership style and the performance of elementary school teachers in Kisam Tinggi District using the product-moment correlation obtained the $\mathrm{XX1Y}$ value of zero point seven hundred twenty-five. These results indicate that the value of rX1Y is greater than the value of an r-table, which is equal to zero point one hundred and seventy-eight. Thus, there is a positive effect between the principal's leadership style and primary school teachers' performance in Kisam Tinggi District. The 
results of the calculation of simple linear regression analysis obtained an $\mathrm{R}$ square score of zero point five hundred and twenty-five, which means that the principal's leadership style variable influences fifty-two point five percent of the teacher performance variable.

This study's results are consistent with the research conducted "The Effect of Principal Leadership Style on Teacher Performance at SMK Negeri 11 Bandung". The conclusion of this study is: "There is a positive and significant effect between the principal's leadership style and performance. There were $17 \%$ of teachers with the coefficient of determination of the principal's leadership style variable on teacher performance. This shows that the leadership style could influence the teachers' performance by seventeen percent and other factors affect the remaining eighty-three percent. It's just that in this study, the leadership style has a greater influence on the performance of teachers in Kisam Tinggi District. This could be affected by certain components owned by the principal in Kisam Tinggi sub-district. Overall, based on these two studies, it could be concluded that the leadership style influenced teacher performance.

The calculation of simple linear regression analysis obtained by the regression line equation is $\mathrm{Y}^{\prime}=$ Thirty-three point six hundred thirty plus zero point seven hundred two $X$. This means that the teacher performance value is thirty-three point six hundred and thirty if there is no change in the principal force leadership value. Meanwhile, the B coefficient value is zero point seven hundred two, which means that each additional value of 1 in the principal's leadership style variable means that the teacher performance value will increase by zero points seven hundred two. In the table, the value of $\mathrm{t}=$ Eleven point four hundred and seventy-one with a significant $t$ of zero points zero zero zero. <zero point zero five, the value of $\mathrm{t}$ table with $\mathrm{df}=$ $\mathrm{nk}=$ one hundred and twenty-one minus two is equal to one hundred and nineteen, then the t-table is two point zero one.

Therefore, the hypothesis reads HO: there is no positive and significant influence between the principal's leadership style on teacher performance and is rejected. The Ha: hypothesis says a positive and significant influence between the principal's leadership style on teacher performance is accepted. This proves a positive and significant influence between the principal's leadership style on teacher performance.

This is in line with the results of Hadi (2020) research entitled The Influence of Principal Leadership
Style and School Environment on Teacher Performance. There is a significant influence of the principal's leadership style on SDN teachers' performance in School Cluster 03 Bantaran District, Probolinggo Regency.

School environment with the performance of elementary school teachers in Kisam Tinggi District. The school environment's calculation of elementary school teachers' performance in Kisam Tinggi District using the product-moment correlation obtained the rX1Y value of 0.600 . These results indicate that the value of $\mathrm{rX} 2 \mathrm{Y}$ is greater than the value of $\mathrm{r}$ table, which is equal to 0.278 . Thus, there is a positive influence between the school environment and primary school teachers' performance in Kisam Tinggi District.

The analysis results obtained an $\mathrm{R}$ square score of 0.360 , which means that the principal's leadership style variable influences $36 \%$ of the teacher's performance variable. Other variables outside of this study influence the remaining 64\%. The simple linear regression analysis calculation obtained from the regression line equation is $\mathrm{Y}^{\prime}=43.296+0.591 \mathrm{X} 1$. This means that teacher performance's constant value is 43.296 if the school environment's value is fixed. The value of teacher performance will increase by 0.591 every time there is an additional value of 1 in the school work environment variable.

Based on the value of $\mathrm{t}$ count $=8.189$ with a significant $t$ of $0.000<0.05$, the value of $t$ table with $\mathrm{df}$ $=\mathrm{nk}=121-2=119$ obtained $\mathrm{t}$ table of 0.67 . Then tcount $>$ $\mathrm{t}$-table. Therefore, the hypothesis reads HO: there is no significant influence between the school environment on teacher performance and is rejected. The hypothesis says that the Ha: accepted. There is a positive and significant influence between the school environment on teacher performance. This proves that there is a significant influence between the principal's leadership style on teacher performance

\section{CONCLUSION}

There is a positive and significant influence between the principal's leadership style on elementary school teachers' performance in Kisam Tinggi District with a rX1Y value of $0.725>$ r-table 0.178 , so there is a positive influence between the leadership style of the head. Schools on the performance of elementary school teachers in Kisam Tinggi District. The R square value is 0.525 , which means that the principal's leadership style influences $52.5 \%$ of teacher performance. The positive and significant influence of the school environment on 
the performance of basic teachers in Kisam Tinggi District. There is a positive influence between professional competence and elementary school teachers' performance in Kisam Tinggi District. Thus, there is a positive influence between the principal's leadership style and the school environment with elementary school teachers' performance in Kisam Tinggi District. Multiple regression analysis R square is 0.564 , which means that the principal's leadership style variable influences $56.4 \%$ of teacher performance variables. Other variables outside of this study influence the remaining $43.6 \%$.

\section{REFERENCES}

[1] Ihsan, F. (2013). Dasar-dasar Pendidikan. Jakarta: Rineka Cipta.

[2] Bacal, R. (2012). Performance Management Terjemahan Surya Dharma dan Yanuar Irawan, Penerbit Gramedia Pustaka.

[3] Bernardin, H., \& John, R. (2010). Human Resource Management. New York: McGraw-Hill

[4] Mardiyoko, T. (2013). "Kontribusi Kompetensi Profesional Guru dan Kreativitas Guru Terhadap Kinerja Guru dalam Pembelajaran Di SMP Negeri Kota Salatiga". Teknologi Pendidikan. Vol (1): No. 1, h. 83-92.

[5] Mathis., \& Jackson. (2010). Manajemen Sumber Daya Manusia. Penterjemah Jimmy Sadeli dan Bayu Prawira Hie. Jakarta: PT. Salemba Empat.

[6] Mulyasa, E. (2012). Manajemen Berbasis Sekolah, Bandung: PT. Remaja Rosdakarya.

[7] Husaini., \& Fitria, H. (2019). "Manajemen Kepemimpinan pada LembagaPendidikan Islam. Jurnal Manajemen, Kepemimpinan dan Supervisi

[8] Hadi, S. (2014). Penelitian Research. Yogyakarta: BPFE 